\title{
Correspondence
}

\section{Calibration of peak flow meters}

SIR,- - The performance of peak flow meters has been assessed by having subjects blow into each meter alternately. ${ }^{1}$ This is a poor technique for the subject does not always produce the same peak flow. To overcome this Oldham et $a l^{2}$ developed a housing which allowed two meters to be connected in series. Obviously the housing has some modifying effect on the meters. We have been able to assess this by means of an independent calibration procedure. ${ }^{3}$

Two mini-Wright peak flow meters (A and B) with apparently repositioned scales were used in the assessment. Each meter was checked on its own for accuracy and repeatability of readings. The two were then calibrated in series using the proposed housing. The position of the meters in the housing was changed and the calibration repeated. Percentage errors for the three sets of readings-that is, independent calibration, meter $A$ upstream, meter B upstream - were then calculated as follows:

$$
\% \text { error }=\frac{\text { (meter reading-actual flow) }}{\text { actual flow }} \times 100
$$

The table shows \% error for the two sets of readings using the housing. The errors shown for the meters in the upstream position were in close agreement with the errors produced during individual calibration. For the meters tested there were wide

\begin{tabular}{|c|c|c|c|c|}
\hline \multirow[t]{2}{*}{$\begin{array}{l}\text { Actual flow } \\
\left(l / \mathrm{min}^{-1}\right)\end{array}$} & \multicolumn{2}{|c|}{$\begin{array}{l}\text { Percentage error for } \\
\text { meter } A\end{array}$} & \multicolumn{2}{|c|}{$\begin{array}{l}\text { Percentage error for } \\
\text { meter } B\end{array}$} \\
\hline & $\begin{array}{l}\text { Upstream } \\
\text { of } B\end{array}$ & $\begin{array}{l}\text { Downstream } \\
\text { of } B\end{array}$ & $\begin{array}{l}\text { Upstream } \\
\text { of } A\end{array}$ & $\begin{array}{l}\text { Downstream } \\
\text { of } A\end{array}$ \\
\hline $\begin{array}{l}140 \\
233 \\
269 \\
300 \\
332 \\
410 \\
462\end{array}$ & $\begin{array}{r}+16.5 \\
+18.4 \\
+18.5 \\
+19.6 \\
+17.4 \\
+10.0 \\
+8.2\end{array}$ & $\begin{array}{r}+16.5 \\
+18.8 \\
+23.0 \\
+22.0 \\
+20.5 \\
+12.4 \\
+9.3\end{array}$ & $\begin{array}{l}+35.9 \\
+27.8 \\
+23.0 \\
+22.0 \\
+20.5 \\
+12.4 \\
+12.3\end{array}$ & $\begin{array}{l}+35.9 \\
+30.5 \\
+26.0 \\
+26.0 \\
+23.2 \\
+15.2 \\
+14.7\end{array}$ \\
\hline
\end{tabular}

Table Meters $A$ and $B$ in series discrepancies in accuracy at low flows. It can also be seen that the position of each meter in the housing had only a relatively small modifying effect on $x$ the peak flow. The worst discrepancy was $4.0 \%$ for $\omega$ meter B at a flow of $3001 \mathrm{~min}^{-1}$. It can be concluded that the housing proposed by Oldham et al works reasonably well. However, there are a number of $\infty$ important limitations in using the housing with subjects. The most vital of these is that no reliable 을 information on the overall accuracy of the two instruments can be obtained. For our meters $A$ and $Z$ B there would be no way of determining which meter produced readings closest to the true values.

In our opinion the performance of any measuring instrument is best assessed in terms of accuracy and $\mathbb{\complement}$ repeatability ${ }^{4}$ by means of a proper calibration $\vec{\varphi}$ procedure. This enables a complete picture of the $Q$ performance of, for example, a number of miniWright peak flow meters to be obtained. ${ }^{5}$

$$
\begin{array}{r}
\text { A SHAw } \\
\text { Department of Clinical Physics and } \\
\text { Bio-Engineering, } \\
\text { West of Scotland Health Boards, } \\
11 \text { West Graham Street, } \\
\text { Glasgow }
\end{array}
$$

\section{References}

1 Perks WH, Tams IP, Thompson DA, Prowse K. An evaluation of the mini-Wright peak flow meter. Thorax 1979; 34:79-81.

2 Oldham HG, Bevan MM, McDermott M. Comparison of the new miniature Wright peak flow. meter with the standard Wright peak flow meter. Thorax 1979; 34:807-9.

3 Shaw A, Fisher J, Hughes DW. A flow and 0 volume calibration for respiratory measuring equipment. J Med Eng Technol 1979; 3:248-52. I

4 British Standard 5233. Glossary of terms used in metrology, 1975.

5 Fisher J, Shaw A. Calibration of some Wright 0 peak flow meters. Br J Anaesth 1980; 52:461-4. 